\title{
GOMMENTS
}

\section{THE SUPREME GOURT AND PRETRIAL DETENTION OF JUVENILES: A PRINCIPLED SOLUTION TO A DUE PROGESS DILEMMA}

The detention of juveniles has been characterized as a "staggering" social problem. ${ }^{1}$ Every year, almost half a million children are incarcerated in juvenile detention centers, and possibly an additional 100,000 children are locked up in adult jails. ${ }^{2}$ These high figures may at first seem to reflect the underlying social reality that adolescent crime is on the rise: more than half of all serious crimes in the United States are committed by youths under seventeen. ${ }^{3}$ Yet, over half of all detained juveniles are held not as delinquents, but while still awaiting an adjudication of their delinquency petitions. ${ }^{4}$ Moreover, the majority of these detained juveniles are released upon the eventual adjudication of their case and are not subject to further incarceration. ${ }^{\circ}$

The incarceration of juveniles prior to a full hearing on the merits of the delinquency petition is authorized by statute in almost all jurisdictions. ${ }^{8}$ In contrast to the general rule which permits pretrial deten-

1 The Detention and Jailing of Juveniles: Hearings Before the Subcomm. to Investigate Juvenile Delinquency of the Senate Comm. on the Judiciary, 93d Cong., 1st Sess. 4 (1973) (opening statement of Birch Bayh, Subcomm. Chairman) [hereinafter cited as Hearings].

2 Ferster, Snethen \& Courtless, Juvenile Detention: Protection, Prevention or Punishment?, 38 FordhaM L. Rev. 161, 187 (1969).

s Kaufman, Protecting the Rights of Minors: On Juvenile Autonomy and the Limits of the Law, 52 N.Y.U. L. REv. 1015, 1016 (1977).

- Nat'l Advisory Comm'n on Criminal Justice Standards and Goals, Corrections (1973), reprinted in P. CromWell, G. Killinger, R. SARRI \& H. Solomon, INtroduction to Juvenile Delinguency: TeXt and Readings 378, 379 (1978) [hereinafter cited as CROMWELL].

- For example, of all the juveniles detained before trial in the following areas, only a small percentage were removed from the community upon adjudication-Massachusetts: 25.9\%; Sangamon County, Illinois: 22\%; Trumbull County, Ohio: 19.5\%; Tarrant County, Texas: 9.7\%. See Ferster, Snethen \& Courtless, supra note 2 , at 189 .

- See Comment, A Due Process Dilemma: Pretrial Detention in Juvenile Delinquency, 11 J. Mar. J. Prac. \& Proc. 513, 518-25 (1978). It is important to distinguish the various stages of juvenile delinquency proceedings. Juveniles are brought to police stations either upon a parent's request, a citizen's complaint, or, most typically, by police arrest. At that point, the police make the initial decision whether to release the child or subject him or her to court action. If the decision is to detain, the child is sent to probation intake, where either informal resolution occurs or the child is detained further. If the decision again is to detain, a petition for delinquency is filed and the child is given a detention hearing before a family court judge. At the hearing the judge 
tion of adult accused criminals only for the purpose of ensuring the accused's presence at trial, ${ }^{7}$ accused juveniles in most jurisdictions may be detained for the additional purposes of protecting the community and protecting the juvenile. ${ }^{8}$ These expanded criteria for preadjudicatory detention of juveniles have traditionally been justified by the notion of parens patriae: the state may exercise its surrogate parental authority to protect these juveniles who are especially vulnerable to harm and lacking in mature judgment. ${ }^{\circ}$ Courts were to handle the youth with paternal care not penal authority. ${ }^{10}$

Some commentators have questioned the premises of detention within the juvenile justice system, particularly a perceived failure of the system to deal coherently with the basic issues of individual liberty and volition. ${ }^{11}$ A more readily demonstrable problem, however, is the failure of juvenile pretrial detention to further in practice any of the ideal objectives of the system. ${ }^{12}$ Rather than "treating" the juvenile, the "overwhelmingly negative" impact of detention" ${ }^{13}$ often destroys "any possibility of subsequent rehabilitation."14 The "deplorable condi-

determines whether the child should be released or detained until the adjudicatory hearing on the merits of the delinquency petition. If subsequently adjudicated delinquent, the juvenile may again be released or detained pending the dispositional hearing, at which the judge determines whether the delinquent should be given probation or sentenced to a period of incarceration. See infra notes 57-69 and accompanying text. See generally Creekmore, Brought to Justice? Juveniles, the Courts and the Law, in Cromwell, supra note 4, at 270-98. This Comment addresses only the period of incarceration between the initial detention hearing and the adjudicatory hearing. This period is referred to as "pretrial" or "preadjudicatory" detention, although it should be recognized that technically a juvenile does not have a "trial." The juvenile procedure is considered an adjudication of delinquent or nondelinquent status, not a criminal trial.

7 See, e.g., Hunt v. Roth, 648 F.2d 1148, 1163-64 (8th Cir. 1981), vacated as moot per curiain sub nom. Hunt v. Murphy, 455 U.S. 478 (1982). Only the District of Columbia permits detention of accused criminal adults for the additional purpose of preventing harm to the community. D.C. CoDE ANN. §§ 23-1321 to 23-1322 (1981 \& Supp. 1983). The constitutionality of that statute was upheld in United States v. Edwards, 430 A.2d 1321 (D.C. 1981), cert. denied, 455 U.S. 1022 (1982). See infra text accompanying notes 121-28.

8 For a thorough discussion of the relevant state statutes and the detention criteria contained therein, see Comment, supra note 6, at 518-25.

- See, e.g., In re Gault, 387 U.S. 1, 16-17 (1967); Kent v. United States, 383 U.S. 541, 554-55 (1966); see also Costello \& Worthington, Incarcerating Status Offenders: Attempts to Circumvent the Juvenile Justice and Delinquency Prevention Act, 16 HaRv. C.R.-C.L. L. Rev. 41, 46-47 (1981).

${ }_{10}$ See, e.g., Morris v. D'Amario, 416 A.2d 137, 140 (R.I. 1980).

11 See Kaufman, supra note 3, at 1017.

12 Guggenheim, Paternalism, Prevention, and Punishment: Pretrial Detention of Juveniles, 52 N.Y.U. L. REv. 1064, 1071 (1977) ("Every respected report on pretrial detention of juveniles has concluded that far too many children are detained, for the wrong reasons, in deplorable conditions." (footnote omitted)). (1974).

13 R. SARRI, Under Lock and Key: Juveniles in JaILs and Detention 14

14 Hearings, supra note 1, at 4. 
tions,"16 poor quality of facilities, and minimal amount of treatment afforded incarcerated juveniles led one court to describe juvenile detention as a singularly "onerous experience."16 The youth is removed from family and friends and placed in a setting characterized by abuse, neglect, and stigmatization. ${ }^{17}$ The stark situation is that "some juveniles in detention are brutalized, beaten and exposed to vicious sexual attacks."18

Public interest groups in recent years have launched attacks in court upon various aspects of juvenile pretrial detention, ${ }^{19}$ although direct challenges to the constitutionality of statutes authorizing juvenile pretrial detention have been rare $^{20}$ and unsuccessful. ${ }^{21}$ In Martin $v$. Strasburg, ${ }^{22}$ however, the Court of Appeals for the Second Circuit found unconstitutional a section of the New York Family Court Act which allowed a juvenile awaiting adjudication to be detained if "there is a serious risk that he may before the return date do an act which if committed by an adult would constitute a crime."2s The court held that the section violated due process because it was used "principally, not for preventive purposes, but to impose punishment for unadjudicated criminal acts."24 The Martin opinion is extremely significant because thirty-six other jurisdictions have similar juvenile preventive detention statutes. ${ }^{25}$ After the Second Circuit handed down its decision in Martin, at least three suits were filed challenging other preventive detention statutes. ${ }^{28}$

The Martin decision is currently on appeal to the Supreme Court. ${ }^{27}$ In reviewing this decision, the Court will for the first time

18 See Guggenheim, supra note 12, at 1071.

${ }^{16}$ Moss v. Weaver, 525 F.2d 1258, 1260 (5th Cir. 1976).

27 See In re William M., 3 Cal. 3d 16, 31 n.25, 473 P.2d 737, 747 n.25, 89 Cal. Rptr. 33, 43 n.25 (1970).

18 Hearings, supra note 1 , at 4.

10 See infra notes $49-56$ and accompanying text.

20 For an interesting early article on selecting the proper plaintiff for attacking juvenile pretrial detention statutes and on how states prevent judicial review of the constitutionality of these statutes, see Kolker, The Test Case and Law Reform in the Juvenile Justice System, 1 Yale Rev. L. \& Soc. Action 64 (1970).

${ }^{21}$ See, e.g., People ex rel. Wayburn v. Schupf, 39 N.Y.2d 682, 350 N.E.2d 906, 385 N.Y.S.2d $518(1976)$.

${ }^{22} 689$ F.2d 365 (2d Cir. 1982), prob. juris. noted sub nom. Schall v. Martin, 103 S. Ct. 1765 (Apr. 18, 1983) (Nos. 82-1248, 82-1278).

${ }^{23}$ N.Y. FAM. CT. AcT § 739(a)(ii) (McKinney Supp. 1982). Such statutes are generally referred to as juvenile "preventive detention" statutes.

24689 F.2d at 372 .

25 See Comment, supra note 6, at 522 n.33.

${ }^{26}$ See Colman v. Zimmerman, No. 81-2215 (E.D. Pa.); D.J.R. v. Larson, No. C82-0811W (D.C. Utah); John Doe v. John Harrington, No. 252729 (Super. Ct. of Hartford, Conn.).

27 Probable jurisdiction has been noted sub nom. Schall v. Martin, $103 \mathrm{~S}$. Ct. 
address questions concerning juvenile preadjudicatory rights. A number of Supreme Court decisions have dealt with the issue of which constitutional rights enjoyed by adult criminal defendants should attach to delinquency petition adjudications. ${ }^{28}$ In Martin, the Court will have the opportunity to apply these principles to statutes authorizing preadjudicatory preventive detention. It is the contention of this Comment that a principled reading of these earlier decisions leads inexorably to the conclusion that such statutes are violative of due process.

This Comment begins with a brief overview of the established goals of the juvenile court system and the development of juvenile rights within that system. It then sets forth in more detail the reasoning of the court in the Martin decision, and analyzes that decision in light of Supreme Court precedents dealing first with the prohibition of punishment before adjudication, and second with juvenile rights in the adjudicative setting. The Comment concludes that preadjudicatory preventive detention of juveniles is a violation of the due process clause and should be declared unconstitutional. Such action by the Supreme Court would not impair the legitimate parens patriae goals of the juvenile court system, but would in fact advance those goals.

\section{Juvenile Courts and Juvenile Rights}

The constitutional rights of juveniles have developed within the framework of a separate court system created for the handling of juvenile problems. From the establishment of the first American juvenile court in Illinois in $1899,{ }^{29}$ the unique system was heralded as the fulfillment of liberal ideals and the goal of saving, rather than simply punishing, the child..$^{30}$ Treatment and rehabilitation, the medical model of response to juvenile delinquency, permeated the philosophy of the new court; ${ }^{31}$ it was to be a tribunal where both law and the behavioral sciences guided the court's decisions. ${ }^{32}$ The key to achieving these goals was to be the nonadversarial, informal nature of juvenile court proceedings. Strict rules of evidence and procedure were to be relaxed, and the fatherly family court judge was to determine each child's individual

1765 (Apr. 18, 1983) (Nos 82-1248, 82-1278).

${ }_{28}$ See infra note 38-48 and accompanying text.

29 See generally M. Paulsen \& C. Whitebread, Juvenile Law \& ProceDURE 1-9 (1974); Mack, The Juvenile Court, 23 HARv. L. REv. 104 (1909).

so Hutchins, Foreword to PURSUING Justice fOR THE ChILd vii-viii (M. Rosenheim ed. 1976) [hereinafter cited as PURSuING Justice].

s1 McCarthy, Pre-adjudicatory Rights in Juvenile Court: An Historical and Constitutional Analysis, 42 U. PITT. L. REv. 457, 457-58 (1981).

${ }^{32}$ H. Lou, Juvenile Courts in The UnIted States 2 (1927), quoted in M. Paulsen \& C. Whitebread, supra note 29 , at 3. 
needs and then prescribe the best remedy. ${ }^{33}$

These broad aims of the juvenile justice system are still recognized. "The basic predicate of the Juvenile Court law is that each juvenile be treated as an individual."s4 Today, adjudication of delinquency is not deemed conviction of a crime but rather determination of a "status."ss Juvenile courts are still considered "surrogate parents who exercise parental authority, not penal authority."s6

In the particular context of cases determining adjudicatory rights of juvenile defendants, the Supreme Court has shown sensitivity to the unique position of juvenile courts. "The Juvenile Gourt is theoretically engaged in determining the needs of the child and of society rather than adjudicating criminal conduct. The objectives are to provide measures of guidance and rehabilitation for the child and protection for society, not to fix criminal responsibility, guilt and punishment."37

Concurrent with this respect exhibited by the Supreme Court for the philosophy of the juvenile justice system, has come an acknowledgment by the Court that the concepts of treating juvenile ills through the use of informal procedures and an emphasis on rehabilitation might not be providing an adequate remedy in practice. In 1966, in Kent $v$. United States, ${ }^{38}$ the Court voiced its concern:

There is much evidence that some juvenile courts . . . lack the personnel, facilities and techniques to perform adequately as representatives of the State in a parens patriae capacity. . . . There is evidence, in fact, that there may be grounds for concern that the child receives the worst of both worlds: that he gets neither the protections accorded to adults nor the solicitous care and regenerative treatment postulated for children. ${ }^{38}$

Kent $v$. United States was thus the beginning of a line of cases in which the Supreme Court delineated the constitutional rights that attach to the adjudicative phase ${ }^{\mathbf{4 0}}$ of juvenile court proceedings. In Kent, the Court held that a juvenile court hearing which waived jurisdiction over the juvenile defendant and remitted the case to an adult tribunal

ss M. Paulsen \& C. Whitebread, supra note 29, at 2-3. (1970).

st In re William M., 3 Cal. 3d 16, 31, 473 P.2d 737, 748, 89 Cal. Rptr. 33, 44

3s United States v. Gonzalez-Cervantes, 668 F.2d 1073, 1076 (9th Cir. 1981).

so Morris v. D'Amario, 416 A.2d 137, 140 (R.I. 1980).

s7 Kent v. United States, 383 U.S. 541, 554 (1966).

s8 Id.

39 Id. at 555-56 (footnote omitted).

40 See supra note 6. 
"must measure up to the essentials of due process and fair treatment."41 One year later, in In re Gault, ${ }^{42}$ the Court stated that an arrested juvenile must receive proper notification of the charges against him, ${ }^{48}$ that a juvenile has a right to appointed counsel at the hearing on the delinquency petition, ${ }^{44}$ and that at the hearing the juvenile enjoys the privilege against self-incrimination as well as the right to confront and cross-examine witnesses. ${ }^{45}$ The charges against the juvenile, the Court said later in In re Winship, ${ }^{46}$ must be proven beyond a reasonable doubt. In Breed $v$. Jones, ${ }^{47}$ the Court held that an adjudication of delinquency followed by prosecution as an adult for the same crime violates the double jeopardy clause. ${ }^{48}$

While the Supreme Court has sketched the framework for juvenile adjudicatory rights, it has not yet confronted issues concerning juvenile preadjudicatory rights. Nevertheless, many lower courts have addressed such issues. $^{4 \theta}$ For example, despite strong support in the literature ${ }^{50}$ most courts have denied juveniles awaiting adjudication the right to bail. $^{\text {s1 }}$ The courts have split on the issue whether juveniles detained prior to adjudication are entitled to a probable cause hearing. ${ }^{62}$ Courts have also found the predispositional detention of juveniles in facilities

41 Id. at 562 .

42387 U.S. 1 (1967).

43 Id. at $31-34$.

4 Id. at 34-42.

45 Id. at $42-57$.

18397 U.S. 358 (1970).

4721 U.S. 519 (1975).

48 But cf. Swisher v. Brady, 438 U.S. 204 (1978) (no violation of double jeopardy when at the adjudicatory hearing the state is permitted to file exceptions to the master's findings on the delinquency charges); McKeiver v. Pennsylvania, 403 U.S. 528 (1971) (plurality opinion) (the Court concluded that a trial by jury is not constitutionally required in the adjudicative phase of a juvenile court delinquency proceeding).

49 It should be noted, however, that as of 1973 , the courts of at least 36 states had yet to address such significant issues of the preadjudicatory phase as the length of time a juvenile may be held before a detention or adjudicatory hearing, the permissible standards for juvenile pretrial detention, or the permissibility of detaining juveniles in the same facilities as adults. Hearings, supra note 1, at 408-18 (memorandum of the American Law Division of the Library of Congress).

so E.g., Wald, Pretrial Detention for Juveniles, in Pursuing Justice, supra note 30, at 122-24; Comment, supra note 6, at 543-47. But see Guggenheim, supra note 12, at $1081-85$.

s1 E.g., Pauley v. Gross, 1 Kan. App. 2d 736, 574 P.2d 234, 240 (1977); State v. Gleason, 404 A.2d 573 (Me. 1979); Morris v. D'Amario, 416 A.2d 137 (R.I. 1980). But see Doe v. State, 487 P.2d 47 (Alaska 1971).

52 The courts mandating a probable cause hearing include Moss v. Weaver, 525 F.2d 1258 (5th Cir. 1976); Thomas v. Mears, 474 F. Supp. 908 (E.D. Ark. 1979). But see Morris v. D'Amario, 416 A.2d 137 (R.I. 1980) (finding no right to a probable cause hearing). See generally Hoffman \& McCarthy, Juvenile Detention Hearings: The Case for a Probable Cause Deternination, 15 Santa Clara L. Rev. 267 (1975). 
for adult offenders impermissible. ${ }^{. s}$

Several aspects of the preadjudication detention hearing - at which a judge determines whether the juvenile may be released to his guardians or instead must be detained until the full hearing on the delinquency petition-have been successfully challenged in the courts. One court held that the judge's decision to detain must be accompanied by written, specific findings. ${ }^{\text {s4 }}$ Another court held that a blanket rule for detaining all juveniles accused of a particular crime is unconstitutional for it prevents consideration of special facts and circumstances. ${ }^{\text {ss }}$ Also, if the release of the juvenile is essential for the preparation of his or her defense at adjudication, held one court, then the juvenile must be released. ${ }^{\text {s8 }}$

Direct attacks upon the constitutionality of statutes authorizing pretrial detention of juveniles have been largely unsuccessful, however. The following section discusses two challenges to one such statute.

\section{The Schupf AND Martin Decisions}

In New York, as in most jurisdictions, ${ }^{57}$ juvenile delinquency proceedings begin with a decision by the police either to release the child or to detain him for formal proceedings. ${ }^{58}$ If the decision is to detain, the juvenile is sent to probation intake. ${ }^{50}$ The intake process, which consists of interviews by social workers of the accused, his guardian, and the complaining witness, frequently results in informal resolution and dismissal of the charges. ${ }^{80}$ If no such resolution occurs, a petition for delinquency is filed. ${ }^{61}$ Within seventy-two hours of the filing of the petition, $^{62}$ a nonadversarial hearing is held before a judge to determine

ss See, e.g., Baker v. Hamilton, 345 F. Supp. 345 (W.D. Ky. 1972); State ex rel. R.C.F. v. Wilt, 252 S.E.2d 168 (W. Va. 1979). (1970).

st Commonwealth ex rel. Sprowal v. Hendrick, 438 Pa. 435, 265 A.2d 348

ss In re William M., 3 Cal. 3d 16, 473 P.2d 737, 89 Cal. Rptr. 33 (1970).

os Kinney v. Lenon, 425 F.2d 209 (9th Cir. 1970).

s7 For a discussion of the juvenile detention proceedings common to most jurisdictions, see Ferster, Snethen \& Courtless, supra note 2, at 174-86.

${ }_{58}$ N.Y. FAM. Cr. ACT $\S 724$ (McKinney Supp. 1982). A study of California police practices revealed that $66 \%$ of the juveniles referred to the police were detained, while in Seattle the police decided to detain $62 \%$ of the juveniles referred to them. See Ferster, Snethen \& Courtless, supra note 2, at 176.

Bo N.Y. FaM. CT. ACr $\$ 734$ (McKinney Supp. 1982).

so A study of New York family court procedures revealed that $28 \%$ of all delinquency cases are resolved informally at probation intake. See Brief for Intervenor-Appellant at 33, Martin v. Strasburg, 689 F.2d 365 (2d Cir. 1982). A nationwide study found that $43 \%$ are released at probation intake, while another survey found $33 \%$ are released. See Ferster, Snethen \& Courtless, supra note 2, at 179.

61 N.Y. FAM. CT. Act § 731 (McKinney Supp. 1982).

c2 Id. at $\S 739$ (b). 
whether to further detain the juvenile. ${ }^{63}$ The judge may order the juvenile detained if he or she finds "facts and reasons" for believing detention is necessary to ensure the juvenile's presence at the delinquency hearing $^{64}$ or to prevent the juvenile from committing crimes before adjudication. ${ }^{85}$ If detention is ordered, the juvenile is entitled to a probable cause determination within three to six days, ${ }^{66}$ and the hearing on the delinquency petition is expedited. ${ }^{67}$ If adjudicated delinquent, the juvenile is further detained until the dispositional hearing, at which the judge may order release or placement in either a secure or nonsecure facility.$^{68}$ This decision is based upon the needs of the juvenile as determined from the original probation intake report and, in many cases, a diagnostic assessment. ${ }^{68}$

In People ex rel. Wayburn v. Schupf, the highest court of New York rejected both an equal protection and a due process challenge to the section of the New York Family Court Act that permits pretrial detention of juveniles if there is a strong possibility that the juvenile will commit a crime before the date of adjudication. ${ }^{71}$ Applying the strict scrutiny standard of equal protection review, the majority found the statute constitutional because it served a "compelling" government interest in protecting both the community and the juvenile. ${ }^{72}$

The Schupf court found that the discretion afforded to family court judges by the statute did not violate due process. The New York Court of Appeals rejected the argument that, because future criminal behavior can not be scientifically predicted, a decision to detain a juvenile must involve unconstitutional elements of speculation if it is based on a prediction of whether the youth will commit a crime. The court noted that an element of speculation is "necessarily present in the administration of any bail system, in the imposition of alternatively available sentences, [or] in the administration of a parole system." ${ }^{\prime 73}$ Since speculation in such contexts is not unconstitutional, implied the court, neither is the speculation permitted by the challenged statute.

6s Id. at $\S 739$. Although this detention hearing is nonadversarial, and hearsay may be admitted and testimony need not be subject to cross-examination, the juvenile nevertheless has the right to appointed counsel and the right to remain silent. See id. at $\S 741$.

64 Id. at $\S 739(\mathrm{a})(\mathrm{i})$.

${ }^{65} I d$. at $\$ 739$ (a)(ii).

${ }^{68}$ Id. at $\S 739(\mathrm{~b})$.

${ }^{67}$ Id. at $\$ 747$.

68 Id. at $\$ 753$.

Bo Id. at $\S 750$.

7039 N.Y.2d 682, 350 N.E.2d 906, 385 N.Y.S.2d 518 (1976).

71 N.Y. FAM. CT. ACT $\$ 739$ (a)(ii) (McKinney Supp. 1982).

7239 N.Y.2d at 689,350 N.E.2d at $909 ; 385$ N.Y.S.2d at 521.

73 Id. at 690,350 N.E.2d at 910,385 N.Y.S.2d at 522. 
Furthermore, the majority in Schupf was not impressed by statistics indicating that most juveniles who are detained before trial in New York are released upon adjudication. ${ }^{74}$ The court felt that such figures do not suggest that pretrial detainment violates due process. Instead, the court reasoned that such statistics reflect the fact that more information is available to family court judges at the adjudication of delinquency than at the preliminary detention hearing, and that judges at the detention hearings are simply making a cautious decision to detain the juvenile, for his own protection and the protection of society, until more information can be obtained. ${ }^{75}$ Apparently, the majority in Schupf felt that such a cautious decision to detain was a valid exercise of the parens patriae authority of the state.

At issue in Martin v. Strasburg ${ }^{76}$ was the same section of the New York Family Court Act allowing a juvenile to be detained upon a finding at the detention hearing that "there is a serious risk that he may before the return date do an act which if committed by an adult would constitute a crime."77

The federal district court declared this section of the statute unconstitutional. ${ }^{78}$ In reaching this decision, Judge Carter considered the case histories of thirty-four juveniles detained before trial and listened to testimony from several experts of juvenile court processes, including a New York City family court judge, a Legal Aid Society attorney with extensive experience representing juveniles in the New York Family Court, a professor of criminal justice, and the director of child psychology at a Chicago hospital. ${ }^{78}$ Additionally, in sifting through extensive statistical evidence, Judge Carter found that in 1979, of all the juveniles held in pretrial detention on the ground that they might commit a crime before adjudication, over half of them had their petitions dismissed or were placed on probation. ${ }^{80}$

74 Id.

${ }^{75}$ Id.

76689 F.2d 365 (2d Cir. 1982), prob. juris. noted sub nom. Schall v. Martin, 103 S. Ct. 1765 (Apr. 18, 1983) (Nos. 82-1248, 82-1278).

77 N.Y. FAM. CT. ACT § 739(a)(ii) (McKinney Supp. 1982). The other basis for pretrial detention of juveniles in New York, id. at $\$ 739$ (a)(i), which allows detention if there is a "substantial probability that he will not appear in court on the return date," was not challenged in either People ex rel. Wayburn v. Schupf, 39 N.Y.2d 682, 350 N.E.2d 906, 385 N.Y.S.2d 518 (1976) or Martin v. Strasburg, 513 F. Supp. 691 (S.D.N.Y. 1981).

${ }^{78}$ Martin v. Strasburg, 513 F. Supp. 691 (S.D.N.Y. 1981).

79 Id. at 694-95.

80 Id. at 705. On appeal, the Second Circuit found that of the 34 juvenile case histories considered by the district court over two-thirds of those juveniles subject to pretrial detention were never sentenced to further incarceration. 689 F.2d at 369 . These findings are similar to those in other jurisdictions. See supra note 5 and accompanying 
Judge Carter stated that if the equal protection test of strict scrutiny were applied, there could be no "compelling need" for the state to detain the juveniles before adjudication since so many were ultimately released either before or after adjudication. ${ }^{81}$ The judge went on to state, however, that the Supreme Court has yet to subject juvenile classifications to strict scrutiny, and thus the appropriate standard of equal protection review was a rationality test. ${ }^{\mathbf{8 2}}$ The court found that the statute here met the constitutional requirements of equal protection under the "less rigorous yardstick" of rationality. ${ }^{83}$

The court held that the statute nonetheless violated due process requirements in three respects. The first ground was that the statute "gives the judge the license to act arbitrarily and capriciously" in predicting the likelihood of future criminal conduct. ${ }^{84}$ This conclusion was buttressed by the family court judge's testimony that detention decisions are based on the judge's "own personal standards,"85 and by the criminal justice professor's observation that "no method had yet been devised which could predict with any acceptable degree of accuracy that a juvenile shall commit a crime." 88 The second due process violation was the possibility of pretrial detention before a determination of probable cause. Since the "burdens of pretrial detention are substantial to impose on a presumptively innocent man, even when there is probable cause to believe he has committed a crime," impose such a burden on a juvenile without a finding of probable cause was "at war with accepted concepts of due process of law."88 Third, the statute violated due process because it authorized punishment without an adjudication of guilt. ${ }^{89}$ The district court found that pretrial detainment of a juvenile constitutes punishment because it stigmatizes the youth as disreputable, deprives the youth of liberty, and is imposed officially rather than as "the spontaneous act of an errant official."

The district court held that the arbitrariness inherent in a family court judge's detention decision was the "most pernicious" of the statute's due process flaws. ${ }^{81}$ On appeal to the Second Circuit, therefore,

text.
81 Martin, 513 F. Supp. at 705.
${ }^{82}$ Id. at 706.
83 Id.
84 Id. at 707 .
85 Id.
${ }^{86}$ Id. at 708 .
87 Id. at 715 .
88 Id.
80 Id.
90 Id.
91 Id. at 707. 
the parties primarily debated the issue whether, in light of the impossibility of accurately predicting future criminal behavior, the statute was unconstitutional because it gave unfettered discretion to family court judges to make detainment decisions. ${ }^{92}$

The court of appeals, however, affirmed on narrower grounds, declining to address the "serious constitutional questions" whether detention before trial, for the purpose of preventing crime and protecting the community, can ever be permissible. ${ }^{93}$ The court affirmed on the grounds that the statute was "utilized principally, not for preventive purposes, but to impose punishment for unadjudicated criminal acts." Such punishment before adjudication of guilt, held the court, is a violation of due process. ${ }^{95}$ The court of appeals held that the penal detention of youths before trial, on the basis initially of "only . . . a verified petition and later at best upon a finding of probable cause," violated due process because punishment can only be imposed after a judicial determination of guilt beyond a reasonable doubt. ${ }^{96}$

In a concurrence to the court of appeals decision, Judge Newman stated that he believed the statute was unconstitutional because it permitted "liberty to be denied, prior to adjudication of guilt, in the exercise of unfettered discretion as to an issue of considerable uncertainty-likelihood of future criminal behavior."

The following section explores in depth the reasoning of the majority and urges that a principled reading of precedent dealing with punishment of adults before adjudication and due process rights of juveniles in the adjudicatory context requires an affirmance of the Second Circuit.

\section{Principles of Due Process and Affirming the Martin MAJORITY OPINION}

In reviewing the Martin $v$. Strasburg decision, ${ }^{88}$ the Supreme

92 See Brief for Intervenor-Appellant at 62-80, and Brief for Petitioners-Appellees at 48-74. Martin v. Strasburg, 689 F.2d 365 (2d Cir. 1982) [hereinafter cited as Brief for Intervenor-Appellant and Brief for Petitioners-Appellees].

98689 F.2d at 372.

os Id.

os Id. at $372-74$.

28 Id. at 373 .

97 Id. at 375. See also the separate opinion in People ex rel. Wayburn v. Schupf, 39 N.Y.2d 682, 691-94, 350 N.E.2d 906, 911-13, 385 N.Y.S.2d 518, 522-24 (1976) of New York Court of Appeals Judge Fuchsberg who would find the statute unconstitutional for substantially the same reasons as Judge Newman.

${ }^{98} 513$ F. Supp. 691 (S.D.N.Y. 1981), affd, 689 F.2d 365 (2d Cir. 1982), prob. juris. noted sub nom. Schall v. Martin, 103 S. Ct. 1765 (Apr. 18, 1983) (Nos. 82-1248, 82-1278). 
Court will examine the constitutionality of a state statute which authorizes pretrial detention of juveniles, and under which most of the juveniles so detained either have their delinquency petition dismissed or are released upon adjudication; ${ }^{99}$ detention under this statute cannot, under present conditions, further the legitimate goals of the juvenile justice system.

Due process is a flexible concept that calls for such protection as the particular situation demands. ${ }^{100}$ The Supreme Court has expressly reserved questions regarding what due process rights attach to the preadjudicatory aspects of juvenile proceedings ${ }^{\mathbf{1 0 1}}$ (the particular context in Martin). Within the broader context of the overall juvenile justice system, however, the Court has noted that the application of due process requirements should not hamper the unique and positive aspects of that system. ${ }^{102}$ With that caveat in mind, it remains clear that "neither the Fourteenth Amendment nor the Bill of Rights is for adults alone."103 In the adjudicatory sphere, the Court has repeatedly stated that juvenile delinquency proceedings must achieve "fundamental fairness;"104 they "must measure up to the essentials of due process and fair treatment." 105

The Court has not yet explicitly defined the terms "due process" or "fundamental fairness" in its limited analysis of the rights of juveniles. ${ }^{108} \mathrm{~A}$ careful examination of the principles of due process as gleaned from cases dealing with punishment of adults before adjudication and with adjudication of juvenile delinquency, however, reveals that the only proper resolution of the Martin question is an affirmance of the holding of the Second Circuit.

\section{A. Punishment Prior to Adjudication of Guilt: Principles from Adult Cases}

In Bell v. Wolfish, ${ }^{107}$ the Supreme Court declared that under the

og See Jurisdictional Statement of Respondents-Appellants, Schall v. Martin, Nos. 82-1248, 82-1278 (U.S. Supreme Ct. filed Jan., 1983).

${ }_{100}$ E.g., Morrissey v. Brewer, 408 U.S. 471, 481 (1971).

102 See In re Winship, 397 U.S. 358, 359 n.1 (1970); In re Gault, 387 U.S. 1, 31 n.48 (1967).

102 See McKeiver v. Pennsylvania, 403 U.S. 528, 550 (1971).

103 In re Gault, 387 U.S. 1, 13 (1967).

${ }^{104}$ McKeiver v. Pennsylvania, 403 U.S. 528, 543 (1971).

105 Kent v. United States, 383 U.S. 541, 562 (1966), cited in In re Winship, 397 U.S. 358, 359 (1970); In re Gault, 387 U.S. 1, 30 (1967).

${ }^{108}$ See Justice Harlan's separate opinion in In re Gault, 387 U.S. 1, 67 (1967), in which he chided the majority's "failure to provide any discernible standard for the measurement of due process in relation to juvenile proceedings."

107441 U.S. 520 (1979). 
fourteenth amendment's prohibition of deprivation of liberty without due process of law, "a detainee may not be punished prior to an adjudication of guilt." ${ }^{108}$ Bell involved punishment of adults, but its principles are equally applicable to juveniles.

While the rights of juveniles are not identical to those of adults, the Court has "expressly rejected" the distinction between adult criminal prosecutions and juvenile delinquency proceedings as a basis for holding the due process clause inapplicable to the juvenile context. ${ }^{109}$ While the unique philosophy of the juvenile justice system shapes any such application of the due process clause, the fourteenth amendment is not for adults alone. 110 "Good intentions [on the part of the juvenile system] do not themselves obviate the need for criminal due process safeguards" in situations where the child will be "subjected to the loss of his liberty."111 As much as the juvenile's right to notification of the charges against him, ${ }^{112}$ or the rule that those charges must be proven beyond a reasonable doubt, ${ }^{113}$ the right to liberty threatened by punishment prior to adjudication of guilt is clearly an "essential of due process"114 and thus the Bell principle is clearly applicable to juveniles.

In defining punishment in the constitutional sense, the Supreme Court has drawn the important distinction between penal measures and regulatory ones, ${ }^{115}$ the former being imposed properly only after an adjudication of guilt. The Bell Court acknowledged the approach of Kennedy v. Mendoza-Martinez, ${ }^{118}$ in which the Court had described the traditional tests to determine the punitive nature of a sanction:

"Whether the sanction involves an affirmative disability or restraint, whether it has historically been regarded as a punishment, whether it comes into play only on a finding of scienter, whether its operation will promote the traditional aims of punishment-retribution and deterrence, whether the behavior to which it applies is already a crime, whether an alternative purpose to which it may rationally be connected is assignable for it, whether it appears excessive in relation to the alternative purpose assigned are all relevant to

${ }^{108}$ Id. at 535. (1967).

${ }^{100}$ In re Winship, 397 U.S. 358, 365 (1970); In re Gault, 387 U.S. 1, 50-51

${ }_{110}$ In re Gault, 387 U.S. 1, 13 (1967).

111 In re Winship, 397 U.S. 358, 366 (1970).

112 In re Gault, 387 U.S. 1, 31-34 (1967).

113 In re Winship, 397 U.S. 358, 358 (1970).

114 Id. at 359.

115 Bell, 441 U.S. at 537.

116372 U.S. 144 (1963). 
the inquiry, and may often point in differing directions."117

The Mendoza-Martinez tests are appropriate for use in the special context of pretrial juvenile detention challenged in Martin. While the Supreme Court has yet to address questions regarding juvenile preadjudicatory rights, the liberty interests involved in pretrial detention are the same as those at stake in the later adjudicatory hearing: the possibility of stigmatization and confinement. ${ }^{118}$ The Gourt has concluded, as well, that incarceration of the juvenile entails the same loss of liberty and stigmatization experienced by an imprisoned adult. ${ }^{110}$ The specifics of the pretrial juvenile context do not obviate the need for the protection of due process. Those specific factors do, of course, shape an application of the Mendoza-Martinez tests to the statute at issue in Martin.

Detention, at any stage in the criminal process, does not necessarily constitute punishment. ${ }^{120}$ In United States $v$. Edwards, ${ }^{121}$ for example, the Mendoza-Martinez test, as applied to the District of Columbia's adult preventive detention statute, ${ }^{122}$ showed that pretrial detention can be regulatory rather than penal. The law was valid under the due process clause because it operated only under "closely circumscribed" conditions. ${ }^{128}$

The court noted that, under the District of Columbia statute, a judicial officer must find with substantial probability ${ }^{124}$ that a detainee, whose dangerousness has been established, ${ }^{128}$ has committed one of several enumerated violent or dangerous crimes ${ }^{126}$ before detainment prior to trial can be ordered. The court reasoned that such a narrowly drawn statute was not utilized for retribution or deterrence, but was intended to protect the community, and thus served an "alternative purpose" which satisfied the Mendoza-Martinez test. ${ }^{127}$ "[P]retrial detention to prevent repetition of dangerous acts under $\S 23-1322$ (a)(1) by incapacitating the detainee seeks to curtail reasonably predictable conduct, not to punish for prior acts."128

117 Bell, 441 U.S. at 537-38 (quoting from Kennedy v. Mendoza-Martinez, 372

U.S. at 168-69).

118 See Martin, 513 F. Supp. at 715-17.

110 In re Winship, 397 U.S. 358, 367 (1970).

120 Bell, 441 U.S. at 537.

121430 A.2d 1321 (D.C. 1981), cert. denied, 455 U.S. 1022 (1982).

122 D.C. CoDE ANN. § 23-1322 (1973).

123 Edwards, 430 A.2d at 1333.

124 Id. at 1339.

125 Id. at 1332.

128 Id.

127 Id. at 1332-33.

128 Id. at 1332. 
In contrast, the juvenile detention statute at issue in Martin is punitive. Whether detention, clearly an affirmative restraint, has been considered as a punishment historically depends in part on the purposes of that detention. ${ }^{129}$ Nearly all aspects of the handling of juveniles in the justice system have been viewed as distinguishable from the treatment accorded adults; the philosophy of the juvenile system - to rehabilitate rather than to punish-has been universally acknowledged..$^{130}$ At the same time, however, the Supreme Court has admitted that a lack of personnel, facilities, and techniques to allow the state to perform. adequately in a parens patriae capacity has meant that juvenile detainees have not received the regenerative treatment theorized for children. ${ }^{131}$ The testimony in Martin of a family court judge who implements the New York law graphically suggests just how drastically theory eludes reality: it appears that after eventually being adjudicated delinquent, many juveniles are not sentenced to further incarceration because the pretrial detention period is "considered sufficient punishment by the Family Court."132 The New York statute thus operates to promote the traditional retributive aim of punishment.

The Mendoza-Martinez laundry list also calls for an examination of whether an alternative, nonpunitive purpose may be assigned to the statutory sanction, and whether the sanction appears excessive in relation to the alternative purpose. ${ }^{133}$ Pretrial detention of juveniles has been justified, in part, as a measure to protect the community. Detention may be imposed under the New York law, however, on a juvenile who has not been accused of violent or dangerous behavior, ${ }^{134}$ and has

129 Id. at 1332; cf. Trop v. Dulles, 356 U.S. 86 (1958).

180 See supra notes $34-37$ and accompanying text. Although rehabilitationism as a philosophy for use of the adult criminal sanction has lost most of its former influence, see F. Allen, The Decline of the Rehabilitative Ideal: Penal Policy and Social PuRpose (1981), rehabilitationism is often considered, along with retribution and deterrence, to be a historical purpose of punishment. E.g., Ingraham v. Wright, 430 U.S. 651, 686-87 (1977) (White, J., dissenting); United States v. Brown, 381 U.S. 437,458 (1965). The rehabilitative philosophy of the juvenile justice system, of course, is thought to distinguish that system from the adult system. Yet rehabilitative treatment implies that the child is in some way in need of reforming therapy, and thus detention even for "beneficial rehabilitative" purposes may reflect some punitive aspects. While the wisdom of a rehabilitative philosophy should not be questioned in the context of juveniles already adjudicated delinquent, the detention at issue in Martin takes place before even a finding of probable cause that the child has committed a delinquent act, see infra note 136 and accompanying text, and thus does not give fair consideration to the fundamental principles of due process.

291 See supra text accompanying note 38.

132 Martin v. Strasburg, 689 F.2d at 371. It has been suggested by many commentators that family court judges often order pretrial detention of juveniles in order to "teach them a lesson." E.g., Ferster, Snethen \& Courtless, supra note 2, at 170-71.

1s3 Mendoza-Martinez, 372 U.S. at 168-69.

134 Martin v: Strasberg, 689 F.2d at 368 \& n.15. 
no prior record, ${ }^{195}$ without even a finding of probable cause that the child has committed a delinquent act. ${ }^{138}$

The Edwards court accepted a "community protection" rationale for the District of Columbia preventive detention statute because it sought to curtail reasonably predictable conduct. ${ }^{137}$ Without having to accept the Martin lower court's observations concerning the difficulty of devising a method which can predict with any acceptable degree of accuracy whether a juvenile will commit a crime, ${ }^{138}$ it seems clear that the statutory scheme's "track record" is poor. Approximately two-thirds of those detained under the section of the statute at issue are released before or upon adjudication. ${ }^{138}$ Many children, therefore, are incarcerated and subsequently released due to insufficient evidence of delinquency. ${ }^{140}$ Similarly, for many of those eventually found delinquent, further detention is deemed unnecessary to protect the community, or is unnecessary because the child has been "punished sufficiently."141 The statute goes well beyond curtailing reasonably predictable conduct and, in fact, is excessive in relation to the purpose of protecting the safety of the community.

A second alternative purpose assigned to the detention would be providing for the welfare of the child. Any incapacitation could protect a child by temporarily preventing further delinquency, but, again, the fact that the vast majority of those detained under the statute at issue are released before or upon adjudication indicates excessiveness. The Supreme Court has acknowledged that the child in detention receives "neither the protections accorded to adults nor the solicitous care and regenerative treatment postulated for children."142 Unless the conditions from which a child is removed are demonstrably atrocious, the harm likely to be caused by "overwhelmingly negative" impact of detention $^{148}$ will far outweigh any minimal benefit which might accrue. ${ }^{144}$

The Court of Appeals of New York in People ex rel. Wayburn $v$. $S c h u p f,{ }^{145}$ on the other hand, when faced with the statute's gross excessiveness, suggested that:

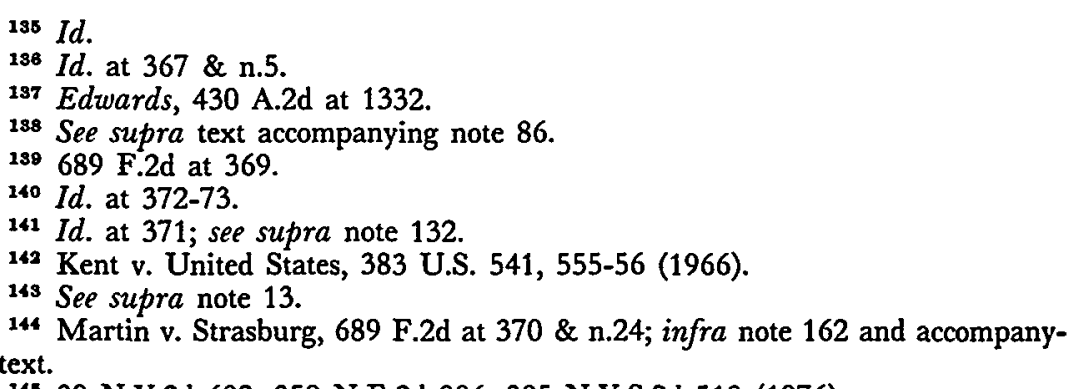

${ }_{145} 39$ N.Y.2d 682, 350 N.E.2d 906, 385 N.Y.S.2d 518 (1976). 
It should surprise no one that caution and concern for both the juvenile and society may indicate the more conservative decision to detain at the very outset, whereas the later development of very much more relevant information may prove that while a finding of delinquency was warranted, placement would not be indicated. ${ }^{148}$

Such an argument misses the point. Pretrial detention is an affirmative restraint clearly implicating liberty interests. While a concern for protecting society may suggest a tendency to detain in close cases, due process requires that a truly nonpunitive societal justification for detention rest on adequate information that indicates the decision will curtail reasonably predictable conduct. ${ }^{147}$ The statutory scheme forces decisions that not only are premature, but that in fact are unconstitutional; the development of the requisite "very much more relevant information" exposes the statute's excessive, distorted better-safe-thansorry approach. ${ }^{148}$ Furthermore, given the reality that the hypothesized "treatment" of juveniles during detention simply does not occur, a conservative decision based on concern for both the juvenile and society would be, in fact, to release the child whenever possible, and thus maximally safeguard the role of the family in protecting and ministering to juveniles. ${ }^{149}$

An application of the fourteenth amendment's prohibition of punishment prior to adjudication and the Mendoza-Martinez test for exposing punitive measures, thus shows the juvenile pretrial detention as authorized by the New York statute to be unconstitutional. It is true, of course, that in New York detained juveniles are entitled to a probable cause hearing within three to six days of the detention hearing. ${ }^{150}$ This procedural safeguard is insufficient to meet the requirements of due process, however, for two reasons. First, the probable cause hearing comes too late. Within three to six days of incarceration, irreparable physical and psychological harm may have already occurred. ${ }^{\mathbf{1 0 1}}$

148 Id. at 690,350 N.E.2d at 910,385 N.Y.S. at 522.

147 Edwards, 430 A.2d at 1332.

148 See supra text accompanying notes 139-40.

14 Kaufman, supra note 3, at 1021.

180 N.Y. FAM. CT. ACT \$ 739(b) (McKinney Supp. 1982).

151 Juvenile hall attendants have expressed surprise at the speed with which relatively innocent youngsters succumb to the infectious miasma of "Juvy" and its practices, attitudes and language. . . . The [detention] experience tells the youngster that he is "no good" and that society has rejected him. So he responds to society's expectation, sees himself as a delinquent, and acts like one.

Aubry, The Nature, Scope and Significance of Pre-trial Detention of Juveniles in Califormia, 1 BlACK L.J. 160, 164 (1971). See also Hearings, supra note 1, at 4 (opening 
Second, "probable cause" is too weak a basis upon which to detain the juvenile. Since preventive detention under this statutory provision is a deprivation of liberty which constitutes punishment, it is important for the Court to acknowledge that the due process requirements pertaining to this practice are indistinguishable from those full protections which govern the adjudicatory hearing: punishment may be imposed only after an adjudication of guilt.

\section{B. Juvenile Cases from the Adjudicatory Context}

In discussing how the fourteenth amendment applies to juveniles, the Supreme Court has repeatedly stated that the juvenile delinquency proceedings must achieve "fundamental fairness."152 The Court has cautioned, at the same time, that the application of due process safeguards must not impair the unique and beneficial aspects of the juvenile court system. ${ }^{153}$ Applying the principles derived from this juvenile adjudicatory context requires the New York juvenile pretrial detention statute to be declared unconstitutional.

\section{Fundamental Fairness}

Overarching the philosophy of the juvenile justice system is the due process clause's requirement of fair treatment. The Court has stated that fundamental fairness and due process for juveniles imply an "emphasis on factfinding procedures."154 The accuracy of factfinding at juvenile delinquency proceedings would be enhanced by permitting the pretrial release of juveniles charged with crime. Just as accused adult criminals are released so they can prepare an adequate defense to the charges against them, ${ }^{185}$ so also would accused juveniles benefit from pretrial freedom. Testifying before the district court in Martin, a Legal Aid Society attorney stated that juvenile pretrial detention has a drastic effect upon the preparation of a case. ${ }^{156}$ The attorney is required to locate and prepare the witnesses by himself, and consultation with the accused juvenile must be done at the detention facility. One court of appeals has held that pretrial release will be ordered when it is neces-

statement of Birch Bayh, Subcomm. Chairman) (relating story of one juvenile who was raped five times in the sheriff's van when being transported from the courthouse to detention).

${ }_{162}$ E.g., McKeiver v. Pennsylvania, 403 U.S. 528, 543 (1971).

16s See infra text accompanying notes 161-73.

154 McKeiver v. Pennsylvania, 403 U.S. 528, 543 (1971) (holding that trial by jury is not a "necessary component of accurate factfinding").

165 See, e.g., United States v. Reese, 463 F.2d 830 (D.C. Cir. 1972).

158 Brief for Petitioners-Appellees, supra note 92, at 42. 
sary for the accused juvenile and his attorney to locate and interview witnesses. ${ }^{107}$ Further, one study indicates that effective representation by and effective consultation with the attorney during the preadjudicative phase is essential to ensure "that the adjudication hearing will concern the facts of the alleged offense."168

Moreover, studies have shown that those juveniles who were detained before trial and eventually adjudicated delinquent receive harsher sentencing than those not subjected to pretrial incarceration. ${ }^{159}$ One commentator has suggested that this is because "[c]onfinement before trial prevents the juvenile from demonstrating a capacity to remain in his home setting, and misbehavior during confinement may be taken as evidence that the youngster should not be allowed to return to his community."160 Detained juveniles, therefore, are automatically prejudiced at the dispositional hearing. This consequence of pretrial detention seems to violate the basic notion behind due process and fundamental fairness.

\section{Preserving Uniqueness}

The Supreme Court has stated that the imposition of due process requirements upon the juvenile justice system must not result in the sacrifice of the unique and positive features of that system. "[E]very aspect of fairness, of concern, of sympathy, and of paternal attention that the juvenile court system contemplates"161 should, according to the Court, be preserved.

In many respects, this paternalistic approach has failed to yield positive results in practice. Nowhere is this more apparent than with the New York pretrial detention procedures at issue in Martin. The horrors of neglect, abuse, and suicide associated with juvenile detention are well-catalogued. ${ }^{162}$ Instead of receiving the regenerative care needed for rehabilitation, the juvenile may acquire additional criminal skills. ${ }^{163}$

${ }^{157}$ Kinney v. Lenon, 425 F.2d 209 (9th Cir. 1970).

158 See Creekmore, supra note 6, at 287. See also National Center for Youth Law, Advocating Access to Counsel for Indigent Juveniles During Pretrial Detention, 14 Clearinghouse Rev. 32 (1980).

160 One study showed that in all of the cases which resulted in placement by the court outside the juvenile's home upon adjudication of delinquency, $86.4 \%$ involved juveniles who had been detained prior to adjudication. See VERA INSTITUTE OF JUStice, Preventive Detention in the District of Columbia, cited in Brief for Petitioners-Appellees, supra note 92, at 43.

${ }_{180}$ Guggenheim, supra note 12 , at $1064-65$ (footnote omitted).

101 McKeiver v. Pennsylvania, 403 U.S. 528, 550 (1971).

102 See, e.g., Hearings, supra note 1, at 3-5 (opening statement of Birch Bayh, Subcomm. Chairman).

${ }^{103}$ See, e.g., Hearings, supra note 1, at 59-68 (statement of George Holland, a 
The unnecessary imposition of such detention, as occurs under the New York statute, is patently at odds with any notion of fairness, concern, or sympathy. Further, the district court in Martin found that the procedures followed at the detention hearing lack any semblance of paternalism. The information before the family court judge consists only of the delinquency petition, the juvenile's record, and the recommendation of the probation officer. ${ }^{164}$ The crucial decision whether to detain the juvenile is made without any diagnostic or psychological assessment, and without any complete understanding of the juvenile's needs. The typical hearing lasts only five to fifteen minutes. ${ }^{165}$ Thus, at least at this stage of the juvenile court proceedings, ${ }^{186}$ there is no opportunity for the juvenile to receive the individual, personal consideration that the system was designed to provide.

By declaring the New York juvenile preventive detention statute unconstitutional, then, the Supreme Court will in no way impair any beneficial aspect of the juvenile justice system. In fact, the Court would be furthering the special goals of the juvenile court system. In his testimony in Martin, the family court judge stated that a major shortcoming of the New York juvenile program is the lack of intermediate treatment facilities. ${ }^{167}$ The judge can only order the juvenile to be placed in such a facility if there is space available and if the facility agrees to accept the juvenile. ${ }^{168}$ The Supreme Court has noted that many of the current abuses in the juvenile courts "relate to the lack of resources."169 It has been shown that the pretrial preventive detention rate of juveniles in New York is excessive and unnecessary. ${ }^{170}$ Curtailing this abuse would reduce administrative costs and reduce the demand for these limited facilities. ${ }^{171}$ The money saved through the elimination of unnecessary

formerly detained youth) (stating that during his period of detention he learned about hustling and for the first time became involved with a gang); see also Clark, Does Incarceration of Juvenile Offenders Reduce Crime? in CROMWELL, supra note 4, at 401-11.

104 Martin, 513 F. Supp. at 702.

108 Id.

186 The court of appeals stated that at the dispositional hearing, which occurs after an adjudication of delinquency, considerably more information concerning the juvenile, including a psychological assessment, is available to the family court judge. 689 F.2d at 370 .

167 See id. at 371.

168 Id.

169 McKeiver v. Pennsylvania, 403 U.S. 528, 548 (1971).

170 See supra note 80 and accompanying text.

171 In fiscal year 1971 , it cost $\$ 456$ million to run the juvenile public detention and correctional facilities, with an average cost of $\$ 6,989$ per inmate that year. See Law Enforcement Assistance Administration, Ghildren in Custody: A Report on the Juvenile Detention and Correctional. Facility Census of 1971 , at 17 (1971). 
detention could be used to create additional, necessary services for the juveniles actually requiring them. ${ }^{172}$ Reducing the detention population and increasing services can only serve to effectuate the original parens patriae goals of the court. ${ }^{173}$

Thus, principles of due process and fundamental fairness as espoused in cases dealing with punishment of adults before adjudication of guilt and with rights of juveniles in the adjudicatory sphere require the Court to uphold the findings of the court of appeals majority in Martin. The New York preventive detention statute is utilized to incarcerate far too many juveniles since most are ultimately released either before or after adjudication, and this procedure is constitutionally impermissible punishment before adjudication of guilt. Further, affirming these findings will not impede but instead will advance the parens patriae goals of the juvenile court.

\section{Principles of Due Process and the Martin CONCURRENCE: UNBRIDLED DisCRETION}

It has been shown thus far that adherence to the prohibition of punishment before adjudication stemming from the due process clause and the principles established by the Supreme Court for analyzing juvenile adjudicatory rights requires the Court to uphold the findings of the court of appeals majority in Martin $v$. Strasburg. ${ }^{174}$ Judge Newman, however, in his concurring opinion, found the juvenile preventive detention statute unconstitutional on different grounds than did the ma-. jority. He declared the practice impermissible because it gave the family court judge "unfettered discretion" to determine the likelihood that

172 For an interesting study on how a community-based program for delinquents cost the local government only one-third as much as traditional incarceration while offering many more services, see C. H. Blew, D. McGillis \& G. BRYANT, AN EXemplary Project-Project New Pride-Denver, Colorado (1977).

178 A somewhat analogous approach was adopted by a juvenile court judge in Atlanta, Georgia. Recognizing the limited juvenile facilities available to the court, the judge set a maximum number for how many juveniles could be treated at those facilities. He then set up a priority system so that the juveniles with the greatest need for detention would be assured treatment. The judge's order is reprinted in INSTITUTE of JUdicial ADMINISTRATION-AMERICAN BAR AsSOciation JOINT COMMISSION ON Juvenile Justice Standards, Interim Status: The Release, Control, and Detention of Accused Juvenile OfFenders Between ARrest and Disposition app. A, 117-19 (1980) [hereinafter cited as IJA-ABA STANDARDS]. Within one year of the judge's order, there was a $57 \%$ drop in the total number of child days in the Child Treatment Center. Id. at 7-8 n.14 (quoting Collins, One Solution to Overcrowded Detention Homes, (No.3) 25 Juv. JusT. 45, 49 (1974)).

174513 F. Supp. 691 (S.D.N.Y. 1981), aff d, 689 F.2d 365 (2d Cir. 1982), prob. juris. noted sub nom. Schall v. Martin, 103 S. Ct. 1765 (Apr. 18, 1983) (Nos. 82-1248, 82-1278). 
the accused might commit a crime before the adjudicatory hearing. ${ }^{175}$ Like the majority, ${ }^{176}$ Judge Newman did not reach the broader issue whether pretrial detention on the basis of a prediction of future behavior is ever constitutionally permissible. ${ }^{\mathbf{1 7 7}}$ Rather, Judge Newman found this statutory provision unconstitutional because it did not contain adequate procedural safeguards to reduce the risk of an erroneous prediction about future criminal activity. ${ }^{178}$

It is true that the juvenile court system was originally based upon the notion of a fatherly family court judge deciding what he thought best served the needs of the accused child. ${ }^{179}$ But the Supreme Court's statement with respect to the "critically important"180 juvenile jurisdiction waiver hearing is equally applicable to the detention statute. The "statute gives the Juvenile Court a substantial degree of discretion . . . [but] does not confer upon the Juvenile Court a license for arbitrary procedure."181 In another context the Court stated that "Juvenile Court history has again demonstrated that unbridled discretion, however benevolently motivated, is frequently a poor substitute for principle and procedure."182 The pretrial detention decision is also "critically important"18s to the juvenile. As Judge Newman correctly pointed out, due process requirements are not met when this decision can be made without reference to any specific criteria or guidelines. ${ }^{184}$

The difficulty with Judge Newman's analysis, however, is that he delineates guidelines which do not completely cure the constitutional error as he described it. He accurately states that "on the present state of knowledge concerning prediction of criminal behavior, only the foolhardy would deny that even with carefully circumscribed decision-making, a significant risk of erroneous prediction remains." ${ }^{\text {"18s }}$ Judge Newman then goes on, however, to list five problems with the current statute which if corrected "would reduce the risk of error."188 Specifically he notes that: 1) "the statute places no limits on the crimes for which the person subject to detention has been arrested," 2) "the judge ordering detention is not required to make any evaluation of the degree

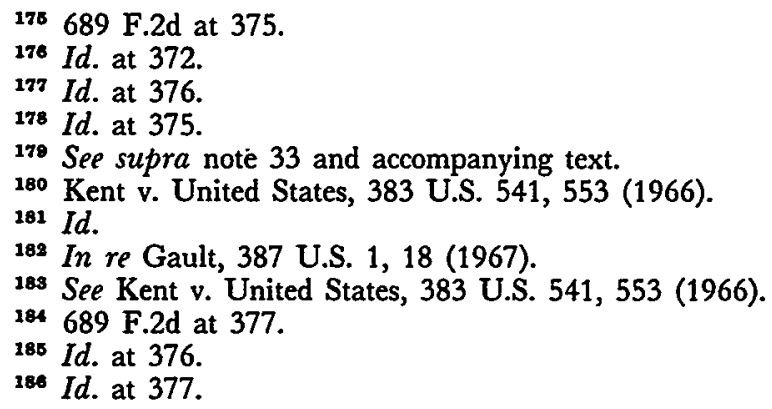


of likelihood that the person committed the crime of which he is accused," 3) "the judge is not required to assess the individual's background," 4) "the statute places no limits on the type of crime that the judge believes the detained juvenile might commit if released," and 5) "the statute does not specify any standard of proof by which the judge must be persuaded of a serious risk of future crime."187 The implicit suggestion, therefore, is that if the New York legislature were to redraft the statute and include these limitations, the statute would pass constitutional muster.

While incorporating these suggestions into the statute might make the decision to detain less discretionary, there is no reason to believe that Judge Newman's safeguards would produce more accurate predictions. The district court, in fact, found, after extensively reviewing the literature and listening to testimony from a criminal justice professor and a clinical psychologist, that researchers and clinicians are currently incapable of predicting the likelihood of future criminal behavior. ${ }^{188}$

The most egregious aspect of the statute is that it is used to incarcerate many juveniles who do not need to be detained. Since there is no indication that Judge Newman's proposals would effectively reduce that high detention rate by eliminating unnecessary confinement, it would be inappropriate for the Supreme Court, in reviewing the Martin decision, to adopt this approach. The more principled approach for the Court to take would be simply to declare the statute unconstitutional.

Such an approach would permit the legislature to reevaluate the entire process surrounding pretrial detention of juveniles. The legislature may conclude, for example, that the concept of juvenile preventive detention is neither practically feasible nor constitutionally permissible, as some commentators have suggested, ${ }^{189}$ and choose not to reenact the statute. New York would then join the ranks of the minority of states which do not permit juvenile preventive detention. ${ }^{190}$ In addition, eliminating preventive detention is consistent with the belief of many commentators that diversion from the juvenile court system is the best method for rehabilitating juvenile delinquents. ${ }^{191}$ Further, studies have

187 Id.

188513 F. Supp. at 707-14.

189 See, e.g., Guggenheim, supra note 12, at 1085-91.

190 See supra text accompanying note 25.

191 See, e.g., National Institute for Juvenile Justice and Delinguency Prevention, Assessing the Relationship of Adult Criminal Careers to Juvenile Careers: A Summary vi (1982); President's Comm'n on Law Enforcement and Admin. of Justice, The Challenge of Crime in a Free Society 79 81 (1967). 
indicated that incarcerating juveniles is ineffective in reducing the juvenile crime rate. ${ }^{\mathbf{1 9 2}}$

Alternatively, the legislature may wish to enact a statute allowing preventive detention only in narrow circumstances, such as if the juvenile is charged with a crime of violence or is an escapee of an institution. ${ }^{193}$ Enacting a more narrowly drawn statute could result in less arbitrary decisionmaking, and more help to the juveniles who actually would benefit from preventive detention. ${ }^{194}$ Some studies have indicated that removing some juveniles from their community is the only effective way to rehabilitate them. ${ }^{185}$

Regardless of the approach adopted by the legislature, it is clear that the Supreme Court should merely declare the current preventive detention statute unconstitutional. This remand to the legislature would require that body to reassess the state's juvenile detention processes, and hopefully provide the opportunity for a renewed commitment to the original parens patriae goals of the juvenile court.

\section{Conclusion}

Pretrial preventive detention of juveniles is authorized by statute in most jurisdictions. Recent studies indicate that most of these detained juveniles will not be sentenced to further incarceration after they receive a full adjudicatory hearing, which has led many commentators to suggest that preventive detention is unnecessary. In Martin v. Strasburg, ${ }^{196}$ the Court of Appeals for the Second Circuit declared New York's juvenile preventive detention statute unconstitutional because the court found the statute was used primarily to impose punishment before a determination of guilt. That decision is currently on appeal to the Supreme Court. 163.

192 See, e.g., A. F. Breed, Purpose of Corrections (1978); Clark, supra note

183 Cf. IJA-ABA STANDARDS, supra note 173, at 78-79 (where the Commission delineates guidelines for the authorization of pretrial detention).

194 Some commentators have suggested that diversion from the juvenile court is an inappropriate way to treat delinquents because it merely results in "benign neglect." See, e.g., Schwendinger \& Schwendinger, Delinquency and Social Reform: A Radical Perspective, in Juvenile Justice: The Progressive Legacy and Current ReFORMS 245-87 (L.T. Empey ed. 1979). Even Professor Guggenheim, who believes juvenile preventive detention should be abolished, concedes that many juveniles are detained because their parents are unwilling to take them home. See Guggenheim, supra note 12 , at 1072.

195 See, e.g., C.A. Murray \& L.A. Cox, Jr., Beyond Probation-Juvenile Corrections and the Chronic Delinguent (1979).

${ }^{106} 513$ F. Supp. 691 (S.D.N.Y. 1981), affd, 689 F.2d 365 (2d Cir. 1982), prob. juris. noted sub nom. Schall v. Martin, 103 S. Ct. 1765 (Apr. 18, 1983) (Nos. 82-1248, 82-1278). 
Due process prohibits punishment before an adjudication of guilt. In several cases involving adults, the Supreme Court has refined and applied a list of factors to determine whether a sanction is punitive or merely regulatory. The detention at issue in Martin fails this test.

The juvenile court was established to serve as an informal, nurturant forum for the treatment of youthful offenders. In a series of cases the Supreme Court stated that the important liberty interests at stake in juvenile proceedings mandate that due process requirements be infused into the juvenile justice system. These requirements must be imposed, however, without impairing the special features of that system.

The unnecessary pretrial detention of juveniles violates the Court's formulation of due process. Eliminating this practice will not eradicate any beneficial aspects of the juvenile court, but will instead decrease the strain on the limited resources available. The Supreme Court, therefore, should affirm the Martin decision. Declaring the statute unconstitutional will provide the legislature with an opportunity to develop juvenile detention procedures that will both respect the due process protection of liberty and better advance the parens patriae objectives of the juvenile court. 


\section{,}

